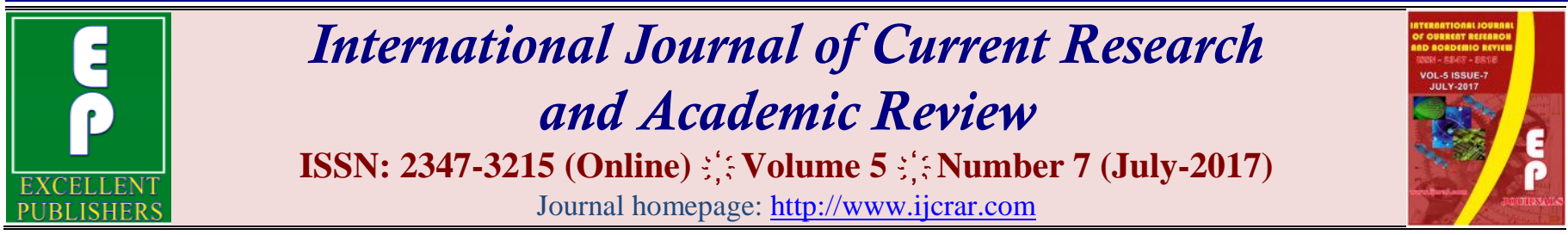

doi: https://doi.org/10.20546/ijcrar.2017.507.012

\title{
Growth Response and Economics of Production of Guinea Fowls Fed Diets Containing Blend of Bovine Blood and Cassava Meal
}

\author{
Iddrisu Alidu ${ }^{1}$, Armstrong Donkoh ${ }^{2}$ and Abdul-Rahaman Saibu Salifu ${ }^{3 *}$ \\ ${ }^{I}$ Department of Science, Bagabaga College of Education, P.O. Box 35E/R, Tamale, Ghana \\ ${ }^{2}$ Department of Animal Science, Kwame Nkrumah University of Science and Technology, Kumasi, Ghana \\ ${ }^{3}$ Department of Ecological Agriculture, Bolgatanga Polytechnic, P.O. Box 767, Bolgatanga, Ghana \\ *Corresponding author:
}

\section{Abstract}

An experiment of 18 -week feeding trial was conducted to assess the effect of four different types of blend of blood and cassava meal, hereafter referred to as BBLOCAM, to partially replace maize on the growth performance and economics of production of guinea fowls. Two hundred and eighty five, five-week old local keets with a mean weight of $85.2 \mathrm{~g}$ were randomly allocated to five dietary treatments in a Completely Randomized Design. Each treatment was replicated three times, with 19 guinea keets per replicate. The dietary treatments consisted of T1 (the control diet), which contained maize as the main energy source; $\mathrm{T}_{2}$ (BBLOCAM II, 25 units blood: 100 units cassava flour: 100 units water), $\mathrm{T}_{3}$ (BBLOCAM III, 50 units blood: 100 units cassava flour 100 units water), $\mathrm{T}_{4}$ (BBLOCAM IV, 75 units blood: 100 units cassava flour: 100 units water) and $\mathrm{T}_{5}$ (BBLOCAM V, 100 units blood: 100 units cassava flour: 100 units water). Feed and water were provided ad libitum. The mean feed consumption values per bird for the 18 -week period were 5.38, 5.50, 5.48, 5.46 and $5.39 \mathrm{Kg}$ for $\mathrm{T} 1, \mathrm{~T} 2, \mathrm{~T} 3, \mathrm{~T} 4$ and $\mathrm{T} 5$ diets respectively with a corresponding mean daily feed intakes of 42.63g (T1), 43.56g (T2), 43.50g (T3), 43.33g (T4) and 42.69g (T5). There were no significant $(\mathrm{P}>0.05)$ differences among treatment means for body weight gain. The mean body weight gain was $0.996 \mathrm{Kg}, 0.958 \mathrm{Kg}, 0.983 \mathrm{Kg}, 0.965 \mathrm{Kg}$ and $0.943 \mathrm{Kg}$ for the dietary treatments of $\mathrm{T} 1, \mathrm{~T} 2, \mathrm{~T} 3, \mathrm{~T} 4$ and $\mathrm{T} 5$ respectively. The feed conversion ratio, gastrointestinal tract, liver, gizzard with exception of carcass weight were statistically $(\mathrm{P}>0.05)$ similar among treatment means. The results indicated that, using BBLOCAM-base diets could result in economic savings up to $\mathrm{GH} \notin 70.00$ per metric tonne and could lead to increase production of guinea fowls making the prices of guinea fowls and their products more affordable to the ordinary Ghanaian.
\end{abstract}

\section{Article Info}

Accepted: 02 June 2017

Available Online: 20 July 2017

\section{Keywords}

Growth response,

Production,

Guinea fowl, Blood,

Cassava meal.

\section{Introduction}

The Guinea fowl (Numida meleagris) is a bird native to Africa (Smith, 1990; Payne, 1990). They are relatively disease-free and require little water or attention (NRC,
1991). The capital investment for engaging in the rearing of Guinea fowl is low and this makes it possible literally for anyone to raise Guinea fowls. Therefore, their potential as an asset for poverty reduction is great especially for disadvantaged groups such as women and 
children (Naazie et al., 2002). Northern parts of Ghana represent the major zone of production of this bird in the country and in almost all households; males and females as well as children rear these birds (Naazie et al., 2002).

Guinea fowls are an integral part of the lives of the people of Northern Ghana and are used for varied functions including; courtship and dowry, gifts and sacrifice (Naazie et al., 2002). They also serve as a means of individual and social wealth generation since ruminants are bought from initial investment in Guinea fowl rearing (Karbo et al., 2002). The bird is also used by the Dagombas, Mamprusisand Gonjasin the Northern region for the celebration of Guinea fowl festival. In Ghana, the Guinea fowl is usually raised under the extensive system just as the local fowl where they fend for themselves by scavenging. As a result, their productivity is very low. Factors responsible for low productivity include; inadequate nutrition, high mortality of keets, worm infestation, predation and poor egg hatchability (Karbo et al., 2002).

Inadequate nutrition has been singled out as one of the key factors affecting productivity. A shift to ingredients for which there is less competition between man and animals, such as agro-industrial by-products or nonconventional feed stuffs, might help if they are sufficiently available (Oluyemi and Roberts, 1988). Cassava is produced in abundance in many tropical areas which can be fed to cattle, pigs and poultry (Gopalakrishnan and Lal, 1996; McDonald et al., 2002). The protein content of cassava is very low and therefore its use in poultry diets would require its supplementation with high protein sources such as fishmeal and soyabean meal which are also very expensive. Blood, a slaughter house by-product, is an untapped feed resource in the tropics. It has high protein content and a good amino acid profile which makes it a potential replacement for the expensive soya bean meal or fishmeal. Blood meal has a crude protein content of $800 \mathrm{~g} / \mathrm{kg}(80 \%)$, and a source of lysine, arginine, methionine, cystine (McDonald et al., 1987; Pond et al., 1995).

The use of blend of blood and ground corncobs (BLOMC) as a replacement for wheat bran up to a level of $120 \mathrm{~g} / \mathrm{kg}$ diet in broiler chickens with positive effects on growth performance (Donkoh et al., 2003).

The objective of the study was to determine the growth performance and the economics of production of Guinea fowls fed diets containing a blend of blood and cassava (BBLOCAM) as partial replacement for maize.

\section{Materials and Methods}

\section{Location and duration of the experiment}

An eighteen-week study was carried out at the Poultry Section of the Animal Science Department of the Kwame Nkrumah University of Science and Technology (KNUST), Kumasi. The area lies within latitude $06^{\circ}$ $43^{\prime} \mathrm{N}$ and longitude $01^{\circ} 36^{\prime} \mathrm{W}$ in the forest zone of Ghana. The environmental temperature generally fluctuates between $21^{\circ} \mathrm{C}$ and $34^{\circ} \mathrm{C}$. High temperatures occur during the months of November to April with average maximum temperatures occurring in February and March while the lowest are experienced in July. Rainfall in the area is basically bimodal with an annual mean of $1500 \mathrm{~mm}$. The rainy season covers April to June and September to October. A short dry season separates the two periods in August. The major dry season (Harmattan) lasts from November to February (Tuah et al., 1990).

\section{Experimental animals and management}

A total of 285 five-week old local breed of the helmet Guinea fowl, with a mean weight of $85.2 \mathrm{~g}$, was purchased from the Poultry Section of the Pong-Tamale Animal Production Department in the Northern Region of Ghana and used for the 18-week experiment. All the birds were raised in a deep litter house with a concrete floor. The pens were partitioned with wire mesh. The 5week old keets were allocated to one of the five treatments in a Completely Randomised Design (CRD). In all, there were 15 replicates with a floor spacing of $2.84 \mathrm{~m} \mathrm{x} 1.63 \mathrm{~m}$ and $1.83 \mathrm{~m}$ each in length, breadth and height respectively. The keets had free access to their respective diets for an 18-week period and water was available ad libitum.

\section{Sources of blood and cassava}

The fresh blood (bovine blood) used in the study was obtained from the Kumasi Abattoir as a by- product of the slaughtering activities. It was kept in clean plastic containers and transported to the experiment site. The peeled sun-dried cassava was obtained from Salaga market in the Northern Region. The dried cassava was milled in a hammer mill to obtain the cassava flour.

\section{Preparation of the blend of blood and cassava meal}

The blood, cassava flour and hot water at $100^{\circ} \mathrm{Cwere}$ mixed on weight basis in the ratios of 1:4:4, 2:4:4, 3:4:4, 
4:4:4 for BBLOCAM II, III, IV and V, respectively (Table 1). The mixture was heated and stirred regularly for 10 minutes to avoid denaturing of the proteins and lump forming. It was then taken off from the fire, allowed to cool and moulded into balls and sun dried for 7 days. The products were then designated as "Blend of blood and cassava meal" (BBLOCAM) II III, IV, V (Table 1) and stored in bags until used for formulating the various experimental diets.

\section{Dietary treatments}

The experimental diets used in the experiment are shown in Table 2. The control diet, designated as dietary treatment 1, contained none of the BBLOCAM formulations. The other BBLOCAM based-diets, designated as dietary treatment $2,3,4$ and 5 contained $10 \%$ each of the various types of BBLOCAM to replace part of the maize portion in the diet.

\section{Parameters measured}

During the experiment, weekly feed intake and weekly weight gains were recorded and corresponding average daily feed intake and average daily weight gain were calculated. Feed conversion efficiency was calculated and records of mortality were also kept. At 23 weeks of age, 4 guinea fowls each from the 15 replicates were selected at random, starved of feed for 18 hours to empty their crops. The birds were slaughtered by cutting the jugular vein, exsanguinated, defeathered and eviscerated. The heart, liver, gizzard and intestine were excised and weighed accordingly.

\section{Chemical and statistical analyses}

The proximate composition of the four types of BBLOCAM and the five experimental diets were determined using Association of Official Analytical Chemists (1990). All data collected were subjected to analysis of variance using GenStat (Discovery Edition 4) and means were separated by least significant difference (LSD) at 5\%.

\section{Results and Discussion}

\section{Nutrient composition of BBLOCAM}

The proximate composition of the four types of BBLOCAM compared to other energy sources is shown in Table 3. The various blend of cassava and blood (BBLOCAM; II, III, and IV and V) had the lowest dry matter percentage $(86.00,86.00,85.50$, and 86.25) respectively contrary to the values reported by Onifade and Tewe (1993) and Akinfala et al., (2002). The blend or product designated as BBLOCAM V, registered the highest crude protein $(21.03 \%)$ content compared to maize meal and cassava root meal (9.89, and 2.25) respectively.

Cassava root meal compared with the four types of BBLOCAM and maize contained the highest NFE $(92.15 \%)$ among other energy sources. The ether extract content of maize $(2.43 \%)$ is higher than that of the four types of BBLOCAM and the cassava root meal. The ether extract contents of the four types of BBLOCAM are, however, comparable to that of maize.

Compared to maize and cassava root meal, all the four types of BBLOCAM are lower in their content of crude fibre. The calcium levels obtained for the four types of BBLOCAM ranged from 0.60 to $0.72 \%$ while the phosphorus content ranged from 0.09 to $0.22 \%$, the highest being for BBLOCAM V.

Nevertheless, the results of this study have shown that, the BBLOCAMs particularly (V), could appropriately serve as a cheaper substitute for maize in poultry production, particularly Guinea fowls.

\section{Chemical analysis}

The proximate composition of the five experimental diets were analyzed for dry matter (DM), crude protein (CP), ether extract (EE) and crude fibre (CF) according to the Association of Official Analytical Chemists (1990) standard methods. Calcium and Phosphorus analysis followed the procedure of Fick et al., (1979).

\section{Estimated cost of producing $100 \mathrm{~kg}$ of BBLOCAM}

The blood and cassava flour are of greater interest in terms of cost and availability as raw materials in the manufacture of BBLOCAM. The cost of $100 \mathrm{~kg}$ dried BBLOCAM was estimated to be $\mathrm{GH} \varnothing$ (19.90, 14.41, 13.92 and 13.47) respectively for BBLOCAMs II, III, IV and $\mathrm{V}$, taking into account the raw materials used and operating cost. The costs of producing $100 \mathrm{~kg}$ of BBLOCAMs were lower for BBLOCAMs II, III, IV and $\mathrm{V}$ as compared to the current market price of maize which was $(\mathrm{GH} \phi 54.00 / 100 \mathrm{~kg}$ bag) at the time of the study, indicating a price difference of $\mathrm{GH} \varnothing(34.10,39.59$, 40.08 and 40.53 or $63.15 \%, 73.32 \%, 74.22 \%$ and $75.06 \%$ ). The bovine blood and cassava flour together 
contributed, on an average, very high ( $\mathrm{GH} \not 15.43$ or $88.17 \%$ ) to the overall cost of $100 \mathrm{~kg}$ BBLOCAM. The cost assigned to the blood is actually handling charges or labour cost paid to the abattoir workers who helped in collecting the fresh blood while operating cost include milling, transportation cost and cost of labour.

\section{General health and mortality}

Generally, the birds in the various treatment groups maintained good health during the course of the study and the mortality figures were also relatively low. Postmortem autopsies indicated that the mortalities were not due to the inclusion of BBLOCAM in the diets of the Guinea fowls. A total of 15 mortality cases were recorded during the experimental period. The mortality values in this work were variable and do not follow any particular trend that could be attributed to the inclusion of BBLOCAM. Out of the 15 mortalities, five $(8.77 \%)$ occurred among birds fed the control diet (T1) which was devoid of any of the four BBLOCAMs, four $(7.02 \%)$ occurred among birds fed BBLOCAM V, three (5.26\%) occurred among birds fed BBLOCAM III, two (3.5 1\%) occurred among birds fed the BBLOCAM II and the least mortality was among birds fed the BBLOCAM IV. This observation is in agreement with that obtained by Donkoh et al., (2003) who recorded the highest mortality $(8.33 \%)$ among broilers fed on a control diet as against those fed on a blend of blood and ground maize cob (BLOMC). Dei et al., (2007) also recorded mortality of $8.3 \%$ on only layers fed on diets devoid of a processed product from cassava and blood (PPCB).

\section{Growth performance of the guinea fowls}

The summary of the growth performance of the guinea fowls on the five dietary treatments is shown in Table 5.

\section{Feed intake}

The mean feed consumption values per bird for the 18week period were $5.38,5.50,5.48,5.46$ and $5.39 \mathrm{~kg}$ for T1, T2, T3, T4 and T5 diets respectively (Table 5). This parameter was not significantly $(p>0.05)$ influenced by the inclusion of the various types of BBLOCAM in the diets. This is in line with the results of Mettle (2009) when pigs were used as experimental animals. However, Onyimonyi and Ugwu (2007) recorded significantly $(\mathrm{p}<0.05)$ higher feed intake values when a diet containing a mixture of blood and cassava peel compared to maize-soya bean based diets were fed to broiler chicks. Dei et al., (2007) also reported lower feed intake values when a processed product from cassava and blood was fed to layer chicken.

\section{Body weight changes and efficiency of feed utilisation}

The mean body weight gain values were $0.997,0.958$, 0.964 and $0.943 \mathrm{~kg}$ for T1, T2, T3, T4and T5 dietary treatments respectively (Table 5). There were no significant $(\mathrm{P}>0.05)$ differences among the treatment means with the maize and BBLOCAM-based diets. Adeyemo et al., (2006) recorded similar body weight gain values of $0.996,0.968,0.961$ and $0.941 \mathrm{Kg}$ for guinea fowl growers fed diets containing varying amounts of a mixture of cassava and blood meals from a period of 7 to 20 weeks of age.

Even though, there were no significant $(p>0.05)$ differences among the treatment means for feed conversion ratios, in absolute terms, the birds on the BBLOCAM (T2-T5) based-diets performed poorly compared to their counterparts on the maize-based-diet. Generally, the efficiency of feed conversion values of the local Guinea fowls used in the present study were poor compared to values for broiler chickens and improved broiler Guinea fowls (ISA ESSOR) as reported by Teye et al., (2001). This is in agreement with the observation of Olomu (1983) and Mareko et al., (2006) who reported that local Guinea fowls grow slowly and utilise feed less efficiently compared to broiler chickens and improved breeds of Guinea fowls.

It can therefore be inferred from the poor efficiency of feed utilisation and its subsequent slow growth that, there is the need for intensive selection and improvement in the genetic make-up of the local Guinea fowl and also the identification of other factors which may influence growth performance, such as nutrition, to be able to tap the full potential of Guinea fowl as a rapid source of animal protein.

\section{Economics of production}

The costs of the various diets were $\mathrm{GH} \phi 0.70, \mathrm{GH} \phi 0.66$, $\mathrm{GH} \phi 0.65, \mathrm{GH} \phi 0.64, \mathrm{GH} \phi 0.63 / \mathrm{kg}$ for the T1, T2, T3, T4 and $\mathrm{T} 5$ diets respectively (Table 5). The reduction in the feed cost of the BBLOCAM (T2-T5) diets was due to the $10 \%$ replacement of maize in the control diet. The reduction in maize levels apparently had no $(\mathrm{P}>0.05)$ detrimental effects on the main performance parameters studied i.e. feed intake, feed conversion efficiency and body weight gain. In this current study, the feed cost was reduced in the BBLOCAM-based diets (T2-T5) between 
$\mathrm{GH} \notin 40.00$ - GH $\varnothing 70.00$ per metric tone. The cost of feed per kg body weight of GH\&3.78 in the control (T1) was reduced to GH $\not 3.60$ in the BBLOCAM IV-containing diet (T5) leading to increase profit per bird in the BBLOCAM -based diets. The observation is similar to Donkoh et al., (2003) who fed broiler chickens with diets which contained a blend of corn cob and blood (BLOMC) and reported that the highest profit was obtain with birds on the $120 \mathrm{~g}$ BLOMC kg-1 diet. Similar findings were reported by Dei et al., (2007) who fed layer chickens with processed products from cassava and blood (PPCB) with a resultant reduced total feed cost and improved margin of profit on egg production.

Table.1 Proportions of blood, cassava flour and water for the four BBLOCAM (II, III, IV and V)

\begin{tabular}{|l|l|}
\hline BBLOCAM & Proportions of blood, cassava flour and water \\
\hline II & 25 units blood: 100 units cassavaflour: 100 units water \\
III & 50 units blood: 100 units cassava flour 100 units water \\
IV & 75 units blood: 100 units cassava flour: 100 units water \\
V & 100 units blood: 100 units cassava flour: 100 units water \\
\hline
\end{tabular}

Table.2 Percentage Composition of the experimental diets fed to guinea fowls

\begin{tabular}{|l|l|l|l|l|l|}
\hline Ingredients & $\mathrm{T} 1$ & $\mathrm{~T} 2$ & $\mathrm{~T} 3$ & $\mathrm{~T} 4$ & $\mathrm{~T} 5$ \\
\hline BBLOCAM & 0 & 10.0 & 10.0 & 10.0 & 10.0 \\
Maize & 59.0 & 49.0 & 49.0 & 49.0 & 49.0 \\
Wheat bran & 6.0 & 6.0 & 6.0 & 6.0 & 6.0 \\
Fish meal & 19.0 & 19.0 & 19.0 & 19.0 & 19.0 \\
Soya bean meal & 15.0 & 15.0 & 15.0 & 15.0 & 15.0 \\
Dicalcium phosphate & 0.25 & 0.25 & 0.25 & 0.25 & 0.25 \\
Oyster shell & 0.25 & 0.25 & 0.25 & 0.25 & 0.25 \\
Salt (NaCI) & 0.25 & 0.25 & 0.25 & 0.25 & 0.25 \\
Vitamin premix & 0.25 & 0.25 & 0.25 & 0.25 & 0.25 \\
Total & 100.0 & 100.0 & 100.0 & 100.0 & 100.0 \\
\hline
\end{tabular}

Table.3 Chemical composition of the four types of BBLOCAM; maize and cassava root meal

\begin{tabular}{|l|l|l|l|l|l|l|}
\hline Parameter & BLOCAM II & BLOCAM III & BLOCAM IV & BLOCAM V & Maize $^{\mathbf{a}}$ & Cassava $^{\mathbf{c}}$ Root Meal $^{-}$ \\
\hline DM & 86.00 & 86.00 & 85.50 & 86.25 & 90.75 & 90.32 \\
\hline CP & 7.15 & 8.70 & 10.23 & 21.03 & 9.89 & 2.25 \\
\hline EE & 0.55 & 1.00 & 1.45 & 1.80 & 2.43 & 0.85 \\
\hline CF & 1.06 & 1.06 & 1.57 & 1.03 & 3.86 & 3.40 \\
\hline Ash & - & - & - & - & 1.53 & 1.35 \\
\hline NFE & 86.72 & 87.26 & 86.48 & 77.53 & 82.29 & 92.15 \\
\hline Calcium & 0.64 & 0.68 & 0.60 & 0.72 & - & - \\
\hline Phosphorus & 0.09 & 0.11 & 0.09 & 0.22 & - & - \\
\hline
\end{tabular}

Source: ${ }^{\text {abcd }}$ Onifade and Tewe, (1993)

Table.4 Proximate composition of the five experimental diets

\begin{tabular}{|l|l|l|l|l|l|}
\hline Parameter & T1 (control) & T2 & T3 & T4 & T5 \\
\hline Moisture \% & 13.75 & 13.78 & 13.78 & 13.83 & 13.76 \\
Crude protein (CP) \% & 23.90 & 22.23 & 22.39 & 22.53 & 23.61 \\
Ether extract (EE) \% & 4.00 & 4.10 & 3.90 & 3.65 & 3.75 \\
Crude fibre (CF) \% & 2.26 & 2.14 & 2.14 & 2.20 & 2.14 \\
Calcium (Ca) \% & 0.60 & 0.60 & 0.61 & 0.60 & 0.61 \\
Phosphorus \% & 0.45 & 0.41 & 0.42 & 0.55 & 0.48 \\
Nitrogen free extract (NFE) & 69.25 & 71.00 & 71.05 & 70.97 & 70.08 \\
Metabolisable energy (ME) (Kcal/kg) & 3468.53 & 3484.77 & 3476.10 & 3459.33 & 3470.77 \\
\hline
\end{tabular}


Table.5 Growth performance and organ weight of Guinea fowls fed the experimental diet over the period from 5 to 23 weeks of age

\begin{tabular}{|l|l|l|l|l|l|l|l|}
\hline Parameter & $\begin{array}{l}\mathbf{T}_{\mathbf{1}} \\
\text { (control) }\end{array}$ & $\mathbf{T}_{\mathbf{2}}$ & $\mathbf{T}_{\mathbf{3}}$ & $\mathbf{T}_{\mathbf{4}}$ & $\mathbf{T}_{\mathbf{5}}$ & $\mathbf{L S D}$ & SIG \\
\hline Mean initial body weight, kg & 0.088 & 0.082 & 0.085 & 0.086 & 0.085 & 0.006 & $\mathrm{~ns}$ \\
\hline Mean final body weight, kg & 1.085 & 1.040 & 1.067 & 1.050 & 1.028 & 0.060 & $\mathrm{~ns}$ \\
\hline Mean body weight gain, kg & 0.997 & 0.958 & 0.982 & 0.964 & 0.943 & 0.060 & $\mathrm{~ns}$ \\
\hline Mean feed intake, kg & 5.38 & 5.50 & 5.48 & 5.46 & 5.39 & 0.386 & $\mathrm{~ns}$ \\
\hline $\begin{array}{l}\text { Mean feed conversion ratio, } \mathrm{kg} \\
\text { feed/kg gain }\end{array}$ & 5.40 & 5.74 & 5.58 & 5.66 & 5.71 & 0.45 & $\mathrm{~ns}$ \\
\hline Fead cost/ kg, GH $\varnothing$ & & & & & & & \\
\hline Feed cost/ kg weight gain, GH $\varnothing$ & 0.70 & 0.66 & 0.65 & 0.64 & 0.63 & - & - \\
\hline Profit/bird, GH $\varnothing$ & 3.78 & 3.79 & 3.63 & 3.62 & 3.60 & - & - \\
\hline Weight of carcass organs $(\%$ of LBW) & 5.26 & 5.37 & 5.40 & 5.42 & 5.47 & - & - \\
\hline Mean carcass & $84.2^{\mathrm{ab}}$ & $83.6^{\mathrm{ab}}$ & $81.6^{\mathrm{b}}$ & $82.9^{\mathrm{b}}$ & $86.8^{\mathrm{a}}$ & 3.57 & $*$ \\
\hline Mean gastro intestinal tract & 2.04 & 2.38 & 2.30 & 2.52 & 2.51 & 0.507 & $\mathrm{~ns}$ \\
\hline Mean liver & 1.33 & 1.52 & 1.51 & 1.63 & 1.52 & 0.281 & $\mathrm{~ns}$ \\
\hline Mean gizzard & 1.49 & 1.52 & 1.49 & 1.55 & 1.54 & 0.510 & $\mathrm{~ns}$ \\
\hline
\end{tabular}

\section{Carcass yield and organ weights}

The mean carcass yield of the guinea fowls on the diets containing the various types of BBLOCAM (T2-T5) ranged from $81.6 \%$ to $86.8 \%$ with birds on the dietary treatments $\mathrm{T} 3$ and $\mathrm{T} 4$ recording significantly $(\mathrm{p}<0.05)$ lower carcass yields. The reasons for the significantly lower carcass yields for birds on dietary treatments T3 and $\mathrm{T} 4$ are unclear considering the fact that no significant differences were observed in the final body weight and weight gain values. In general, the carcass yields of the experimental guinea fowls were generally high (up to 86.8\%) compared with that reported for chickens (about 65\%). Koney (1993) attributed the high carcass yields of guinea fowls to the slenderness of the skeleton of Guinea fowls. Mareko et al., (2006) also recorded $94.4 \%$ and $93.59 \%$ dressing out percentage and dress weights of $0.949 \mathrm{Kg}$ and $1.081 \mathrm{Kg}$ for 14 - weekold guinea fowls raised on concrete and earth floors, respectively. There were no significant $(p>0.05)$ differences among the treatment means for gastrointestinal tract, liver and gizzard.

\section{Conclusion}

The results from the study suggest that, the reduction in the inclusion levels of maize in the BBLOCAM diets (T2-T5) resulted in economic savings of up to $\mathrm{GH} \phi$ 70.00 per metric tonne. All carcass parameters with exception of mean carcass yield were statistically $(\mathrm{P}>0.05)$ similar. Blood, by- product from the abattoir as an environmental pollutant, its usage as a feed ingredient for poultry will clean the environment while enhancing the rearing of guinea fowls at a cheaper cost.

The study also revealed that, BBLOCAM IV was the cheapest among all the four BBLOCAMs and it was the best to be used for feeding guinea fowls. It can therefore, be concluded that BBLOCAM can replace maize up to $10 \%$ or more in diets of poultry without compromising growth performance.

\section{References}

Akinfala, E.O., Aderibigbe, A.O., and Matanmi, O. 2002. Evaluation of the nutritive value of whole cassava plant as a replacement for maize in the starter diets for broiler chicken; Livestock Res. Rural Develop., (14)6. Retrieved January 20, 2011,

Adeyemo, A.I., Oyejola, O., and Afolayan, T.A. 2006. Performance of Guinea fowls (Numidameleagris) fed varying protein levels. J. Animals and Vet. Adv., 5: 519-521.

Association of Official Analytical Chemists (AOAC). 1990. Official Methods of Analysis. 5th Edition AOAC, Arlington, VA.

Dei, H.K., Tetteh, E., and Otchere, E.O., 2007. Nutritive value of a processed product from cassava and blood in the diets of layer chickens. Ghanaians $J$. Animal Sci., 2 and 3(1): 45 - 50.

Donkoh, A., Octehere, S., Asare, U.O., Okyere-Boakye, E., Tawiah, R. Y. and Nyannor, E. K. D. 2003. A note on nutritive value of blend of blood and ground 
maize cob for broiler chickens. J. Animal and Feed Sci., 12: 597-603.

Fick, K.R., McDowell, L.R., Miles, P.H., Wilkinson, N.S., Funk, J.D., Conrad, J.H., 1979. Methods of Mineral Analys for Plant and Animal Tissues, 2nd edn. Department of Animal Science, University of Florida, Gainesvelle, USA.

Gopalakrishnan, C.A., and Lal, G.M., 1996. Livestock and Poultry Enterprise for Rural Development. Vikas Publishing House PVT Ltd., India. Pp. 439 534.

Karbo, N., Avornyo, F.K., and Atiiga, S., 2002. Preliminary studies on the pattern and causes of Guinea fowl (Numida melegris) keet losses in Garu, Bawku East District. The Savanna Farmer, 1: 15 17.

Koney, E.B.M. 1993. Poultry Health and Production. Advent Press, Accra - Ghana. pp. 104 - 107.

Mareko, M.H.D., Nsoso, S.J., and Tibelang, K., 2006. Preliminary carcass and meat characteristics of Guinea fowl (Numida meleagris) raised on concrete and earth floors in Botswana. J. Food Technol., 4(4): 313 - 317.

McDonald, P., Edwards, R. A., and Greenhalgh, J.F.D. 1987. Animal Nutrition, 4th edition, Longman Group Ltd, Essex, England. pp. 405-491.

McDonald, P., Edwards, R. A., Greenhalgh, J.F.D., and Morgan, C.A., 2002. Animal Nutrition. 6th Edition. Pearson Prentice Hall, Singapore. pp. 389-614.

Mettle, S.S. 2009. The effects of a cassava peel and blood mixture (Blocassap) on the growth performance of starter-grower pigs. MSc. Thesis. Faculty of Agriculture, Department of Animal Science, Kwame Nkrumah University of Science and Technology, Kumasi, Ghana.

Naazie, A., Canacoo, E.A., and Mwinbong, C. 2002. Guinea Fowl Production in the Upper East Region of Ghana. Final Report to Land Conservation and
Smallholder Rehabilitation Project, Phase II (LACOSREP II), Ministry of Food and Agriculture, Upper East Region, Ghana.

National Research Council (NRC). 1991. Guinea Fowl. In: Micro Livestock, Little Known Small Animals with a Promising Economic Future. National Academy Press, Washington DC. pp. 115 - 123.

Olomu, J.M., 1983. Aspect of the nutrition of the Guinea fowl. In: The Helmet Guinea fowl (J.S.O. Ayeni, J.M. Olomu and T. A. Aire, Eds.), Kainji Lake Research Institute, New Bussa, Nigeria. pp 108-120.

Oluyemi, J.A., and Roberts, F.A. 1988. Poultry Production in Warm Wet Climates. Macmillan. Hong Kong.

Onifade, A.A., and Tewe, O.O. 1993. Alternative tropical energy feed resources in rabbit diets: growth performance, diets digestibility and blood composition. World Rabbit Sci., 1(1): 17-24.

Onyimonyi, A.E., and Ugwu, S.O.S. 2007. Bioeconomic indices of broiler chicks fed varying ratios of cassava peel/bovine blood. Int. J. Poultry Sci., 6(5): $318-321$.

Payne, W.J.A. 1990. An Introduction to Animal Husbandry in the Tropics. 4th Ed. Longman Group Ltd. Singapore. pp. $739-740$.

Pond, G.W., Church, D.C., and Pond, K.R., 1995. Basic Animal Nutrition and Feeding; 4th Edition. John Wiley and Sons, Inc., USA. pp. 309 - 337.

Smith, A.J. 1990. Poultry. Macmillan Publishers Ltd. London and Basingtoke, pp 218.

Teye, G.A., Gyawu, P., and Agbolosu, A.A. 2001. Growth potential and carcass yields of exotic and indigenous guinea fowls in Ghana. Development Spectrum, 1(1): 34-40.

Tuah, A.K., Oppong-Anane, K., and Owusu-Aduomi, K. 1990. Lambing and neonatal behavior of DjalonkexSahel crossbred. Maternal behavior. Ghanaian J. Agri. Sci., 20-23: 111-115.

\section{How to cite this article:}

Iddrisu Alidu, Armstrong Donkoh and Abdul-Rahaman Saibu Salifu. 2017. Growth Response and Economics of Production of Guinea Fowls Fed Diets Containing Blend of Bovine Blood and Cassava Meal. Int.J.Curr.Res.Aca.Rev. 5(7), 88-94. doi: https://doi.org/10.20546/ijcrar.2017.507.012 